Article

\title{
Wear Properties of Sc-Bearing Zr-Based Composite BMG with Nano-CuZr 2 under Lubrication
}

\author{
Shing-Hoa Wang ${ }^{1, *}$, Chau-Chang Chou ${ }^{1, * \mathbb{D}}$, Hsien-Hung Chung ${ }^{2}$, Rong-Tan Huang ${ }^{2}$, \\ Horng-Yi Chang ${ }^{3}$, Cheng-An Hsu ${ }^{1}$ and Peter K. Liaw ${ }^{4}$ (i) \\ 1 Department of Mechanical Engineering, National Taiwan Ocean University, Keelung 20224, Taiwan; \\ mp58972146350@gmail.com \\ 2 Institue of Materials Engineering, National Taiwan Ocean University, Keelung 20224, Taiwan; \\ chrissquare1109@yahoo.com.tw (H.-H.C.); rthuang@ntou.edu.tw (R.-T.H.) \\ 3 Department of Marine Engineering, National Taiwan Ocean University, Keelung 20224, Taiwan; \\ hychang@ntou.edu.tw \\ 4 Department of Materials Science and Engineering, The University of Tennessee, \\ Knoxville, TN 37996-2100, USA; pliaw@utk.edu \\ * Correspondence: shwang@email.ntou.edu.tw (S.-H.W.); cchou@email.ntou.edu.tw (C.-C.C.)
}

Received: 16 June 2020; Accepted: 15 July 2020; Published: 17 July 2020

check for updates

\begin{abstract}
Lubricated sliding wear of amorphous $\left(\mathrm{Zr}_{55} \mathrm{Cu}_{30} \mathrm{Ni}_{10} \mathrm{Al}_{5}\right)_{99.98} \mathrm{Sc}_{0.02} / \mathrm{CuZr}_{2}$ nanocrystal composite bulk metallic glasses (BMG) under various sliding velocities with a load of $20 \mathrm{~N}$ was investigated using the pin-on-disk test. After the wear test involving oil lubrication was performed, there was no wear induced new-phase transformation in the sample surface. Friction coefficients were within the range from 0.22 to approximately 0.29 under a $20-\mathrm{N}$ load at different sliding velocities. Therefore, the calculated friction coefficients clearly indicated that the adhesion wear dominated from the experimental results. This deformation behavior resulted in a higher wear rate and wear coefficient. In addition, worn surfaces were characterized and examined under a scanning electron microscope (SEM) and optical microscope. The mechanism of high wear rate was clarified.
\end{abstract}

Keywords: intermetallics; composite BMG; friction coefficient; wear

\section{Introduction}

Because of BMGs' (bulk metallic glasses) hardness and toughness both being high, they are expected to have superior properties of wear. Literature has pointed out that BMGs have a good wear resistance compared to nanocrystallized materials [1,2]. By contrast, reports have also indicated that the wear performance of BMGs is considerably inferior to that of the annealed materials [3]. For example, Zr-based BMGs were slid under lubricated and dry frictions for $100 \mathrm{~m}$ and $1000 \mathrm{~m}$, respectively. The values of the friction coefficient for the amorphous alloy was slightly lower than that of stainless steel AISI 303 (American Iron and Steel Institute 303) and Ni-200 (commercial pure $\mathrm{Ni}$ ) under the wear of dry environment. However, this trend was not the mode under lubricated conditions [3]. The $\mathrm{Zr}_{41} \mathrm{Ti}_{14} \mathrm{Cu}_{12.5} \mathrm{Ni}_{10} \mathrm{Be}_{22.5} \mathrm{BMG}$-bearing gears have been tested in working life after high-speed rotation testing [4]. The results indicated that the BMG-bearing gear is superior to bearing steel GCr15(YB9-68) under the same conditions. Furthermore, the material was still observed to have a glassy amorphous structure after wear testing. Furthermore, a series of $\mathrm{Zr}_{48} \mathrm{Cu}_{45}-\mathrm{xA}_{17} \mathrm{Ag}_{\mathrm{x}}(x=0-8$ at. $\%)$ BMG alloys have been investigated in terms of their dry sliding wear behaviors; the results of wear tests exhibited a significant increase in wear resistance with the addition of $\mathrm{Ag}$ in the ternary $\mathrm{Zr}-\mathrm{Cu}-\mathrm{Al}$ system [5]. A $\mathrm{Zr}_{41.5} \mathrm{Ti}_{13.8} \mathrm{Cu}_{12.5} \mathrm{Ni}_{10} \mathrm{Be}_{22.5} \mathrm{BMG}$ was tested under sliding experiments; an extensive material flow was determined occurring during dry sliding in the environment of either air or 
vacuum [6]. The friction coefficient in vacuum reduces with an increase in load compared with the environment in air. The sliding wear properties of $\mathrm{Cu}_{60} \mathrm{Zr}_{30} \mathrm{Ti}_{10}$ in various annealing states were compared under dry condition [7]; the wear mechanism involves an easier initiation of crack and crack propagation through the relatively brittle nanocrystalline phases, leading to a nanocrystallized metallic glass exhibiting poor wear performance.

Nanocrystals dispersed in an amorphous matrix by partial nanocrystallization exhibits effective mechanical properties [8,9], favorable soft magnetism [10,11] and hard magnetism [12,13], and excellent properties of corrosion resistance [14]. Those have not been observed for pure amorphous or pure nanocrystalline alloys. Therefore, the novel structure and technological importance of the partially nanocrystallized intermetallic amorphous matrix materials have attracted considerable attention [15]. However, few research works have focused on the tribological properties of composite $\mathrm{BMG}$ or the amorphous matrix with nanocrystal $\mathrm{CuZr}_{2}$. The intermetallic compound of nano- $\mathrm{CuZr}_{2}$ is a thermodynamically stable phase. Meanwhile, $\mathrm{CuZr}_{2}$ is harder than the $\mathrm{Zr}$-based $\left(\mathrm{Zr}_{55} \mathrm{Cu}_{30} \mathrm{Al}_{10} \mathrm{Ni}_{5}\right)_{99.98} \mathrm{Sc}_{0.02}$ bulk amorphous matrix. Therefore, it is an attractive bearing and shaft material for industrial application. The current study focused on the lubricated wear properties after a small amount of Sc (scandium) was added to the Zr-based composite BMG. The small amount of Sc addition can enhance the $\mathrm{Zr}$-based $\left(\mathrm{Zr}_{55} \mathrm{Cu}_{30} \mathrm{Al}_{10} \mathrm{Ni}_{5}\right)_{99.98} \mathrm{Sc}_{0.02}$ composite $\mathrm{BMG}$ glass-forming ability. There are few reports on Sc addition on BMGs. When BMG is used as bearings and shafts, the friction feature of BMG needs to be evaluated comprehensively. In this work, the friction and wear properties of Zr-based BMGs sliding against 440C steel lubricated with industrial oil lubrication was investigated.

\section{Experimental Procedures}

A bulk amorphous $\left(\mathrm{Zr}_{55} \mathrm{Cu}_{30} \mathrm{Al}_{10} \mathrm{Ni}_{5}\right)_{99.98} \mathrm{Sc}_{0.02}$ matrix/CuZr $\mathrm{C}_{2}$ nanocrystal composite BMG (Sc-bearing Zr-based composite BMG) was prepared using a tilt-casting method to produce 3-mm-diameter samples. The advantage of this casting methodology can prevent the flow of molten alloy from cold shuts and suppressing the initiation of crack and crack propagation [16]. The size of composite BMG specimens were $3 \mathrm{~mm}$ in diameter and $5 \mathrm{~mm}$ long. The end of a pin was mounted this composite BMG. The dimension of $440 \mathrm{C}$ steel $(0.95-1.20 \mathrm{wt} . \% \mathrm{C}, 1.00 \mathrm{wt} . \% \mathrm{Mn}, 1.00 \mathrm{wt} . \% \mathrm{Si}$, 16-18 wt.\% Cr, 0.04 wt.\% P, 0.03 wt.\% S, and 0.75 wt.\% Mo and Fe in balance) disk was $36 \mathrm{~mm}$ in diameter and $5 \mathrm{~mm}$ thick. Before testing, the disks were polished using $0.3 \mu \mathrm{m} \mathrm{Al} \mathrm{O}_{3}$ powders to reach the average surface roughness of approximately $0.02-0.015 \mu \mathrm{m}$. Wear tests of sliding were conducted using the apparatus of pin-on-disk (see Appendix A Figure A1) according to the American Society for Testing and Materials (ASTM) G99 [17] and International Organization for Standardization (ISO) VG68 oil lubrication (ISO viscosity classification ISO 3448, 1975). The load at $20 \mathrm{~N}$ was applied normally coupling diverse sliding velocities of $0.043-0.128 \mathrm{~m} / \mathrm{s}$. The average value and standard deviation of the wear rate and friction coefficient were evaluated based on five test results.

To investigate the microstructure of the $\left(\mathrm{Zr}_{55} \mathrm{Cu}_{30} \mathrm{Al}_{10} \mathrm{Ni}_{5}\right)_{99.98} \mathrm{Sc}_{0.02}$ composite BMG before and after the wearing tests, $\mathrm{X}$-ray diffraction (XRD) was conducted using a Bruker-D2-Phaser (Billerica, MA, USA) at $300 \mathrm{~V}$ with $\mathrm{Cu} \mathrm{K} \alpha_{1}(\lambda=0.154 \mathrm{~nm})$ and scanning from 20 degrees to 80 degrees. The thin foils of Zr-based composite BMG were examined by using a field-emission gun transmission electron microscope (FEI Tecnai G2 F30 TEM) operated at $300 \mathrm{kV}$ for high-resolution microstructure observation. The test-specimen and disk both surfaces were ultrasonically cleaned by using acetone to remove the detrimental effect of residual debris from earlier experiments for each test. A load of dead weights pressed the stationary composite BMG sample onto the rotating disk. The frictional force, which was exerted on the test specimen during sliding, was measured by means of a force transducer placed on the pin-holder arm. Before the wear test, the hardness of 440C steel (a high hardenability martensitic stainless steel with high carbon and straight chromium) and composite BMG was measured under a $300 \mathrm{~g}$ load to compare the relative hardness. Before and after wear tests, the mass loss in each test was measured by weighing the tested samples by using an electronic balance with $\pm 0.0001 \mathrm{~g}$ 
precision. The ratios called wear rates, which were defined as the mass loss to the total sliding distance were determined.

\section{Results and Discussion}

The microhardness values of the $440 \mathrm{C}$ steel and $\left(\mathrm{Zr}_{55} \mathrm{Cu}_{30} \mathrm{Al}_{10} \mathrm{Ni}_{5}\right)_{99.98} \mathrm{Sc}_{0.02}$ composite BMG were $686 \mathrm{Hv}$ and $519 \mathrm{Hv}$, respectively, indicating that the Zr-based composite BMG was softer than the $440 \mathrm{C}$ steel. In this material, the as-received glassy matrix, including the $\mathrm{CuZr}_{2}$ nanocrystalline composite phases, was observed using bright-field transmission electron microscopy, and a composite diffraction halo with a spots pattern is displayed inset in Figure 1. A spot pattern indicating a nanocrystal is superimposed on a halo of the amorphous matrix (Figure 1). The wear-tested and as-received amorphous Sc-bearing Zr-based composite BMG mainly consisted of a diffused peak superimposed on nanocrystalline peaks of $\mathrm{CuZr}_{2}$ (Figure 2). No wear induced any new phase formed in the crystalline structure analysis by XRD after the wear test in oil lubrication (Figure 2). The same crystalline structure remained after a wear test under a 20-N load (Figure 2). The reason could be attributed to the fact that the wear-making temperature increase was insufficient for the amorphous matrix at the contact interface to undergo nano-recrystallization under the oil lubrication and cooling effect. Similarly, no difference in hardness between the surface and the matrix was exhibited in $\mathrm{Zr}_{41} \mathrm{Ti}_{13.8} \mathrm{Cu}_{12.5} \mathrm{Ni}_{10} \mathrm{Be}_{22.5}$ BMG-bearing rollers [4], during rotation test with the high-load and high-speed. In particular, a composite BMG was loaded with a relatively lighter load and had a lubricant with cooling effect. Consequently, the composite BMG still kept the original amorphous/nanocrystal composite structure after the wear test. In the test, an ISO VG68 oil stock was used as a lubricant and coolant that greatly contributed to preventing the formation of a new nano-recrystallized phase by stress- or strain-induced phase transformation.

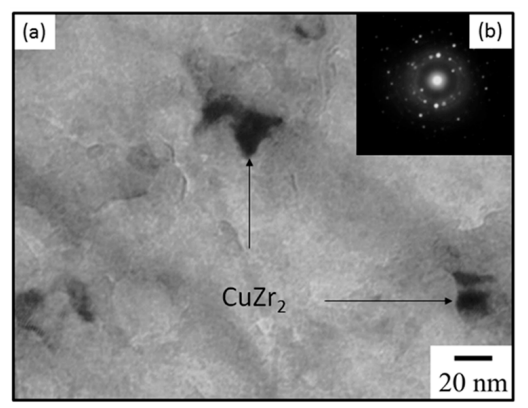

Figure 1. (a) Bright-field image of transmission electron microscope (TEM), and (b) diffraction pattern of the as-received $\left(\mathrm{Zr}_{55} \mathrm{Cu}_{30} \mathrm{Ni}_{10} \mathrm{Al}_{5}\right)_{99.8} \mathrm{Sc}_{0.02}$ composite bulk metallic glass (BMG).

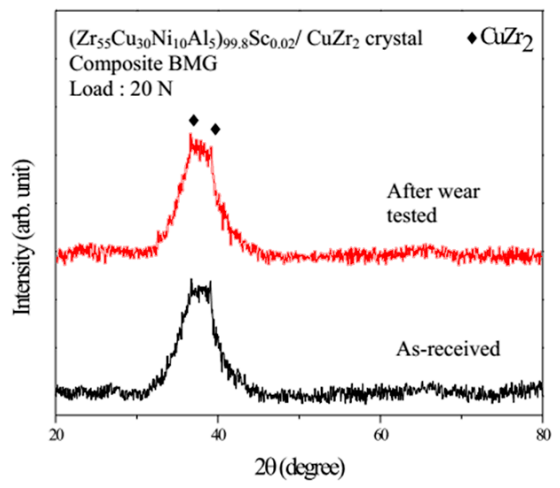

Figure 2. Comparison of $\mathrm{X}$-ray diffraction patterns of the $\left(\mathrm{Zr}_{55} \mathrm{Cu}_{30} \mathrm{Ni}_{10} \mathrm{Al}_{5}\right)_{99.8} \mathrm{Sc}_{0.02}$ composite BMG for the as-received condition and after wear testing under a $20 \mathrm{~N}$ load. 


\subsection{Coefficient of Friction}

A critical form of wear is called adhesive wear characterized by the high wear rates and a high, unstable friction coefficient. Adhesive wear can rapidly destroy the sliding contacts; and sliding motion may be prevented by extremely high friction coefficients, leading to seizure [18]. The coefficient of friction appeared to be slightly unstable (Figure 3). The scattered data points of friction coefficient versus the sliding distance at different sliding velocities under $20 \mathrm{~N}$ were caused by the worn surface having scaled-off debris, patches adhered to the disk surface, and distinct grooves and craters. Also, the scale at $Y$-axis was enlarged in order to make the data points distinct. The values were within the range from 0.22 to approximately 0.29 under a $20-\mathrm{N}$ load at different sliding velocities. When a softer stationary slider is slid against a moving harder disk, the steady-state coefficient of friction is approximately the same [19]. Therefore, the experimental results clearly indicated that the measured friction coefficients can be determined as the adhesion wear. The friction coefficients of the Sc-bearing Zr-based composite BMG were higher than those of the $\left(\mathrm{Cu}_{55} \mathrm{Zr}_{40} \mathrm{Al}_{5}\right)_{98} \mathrm{Er}_{2}$ composite BMG (0.13-0.22) [19], as shown in Figure 4.

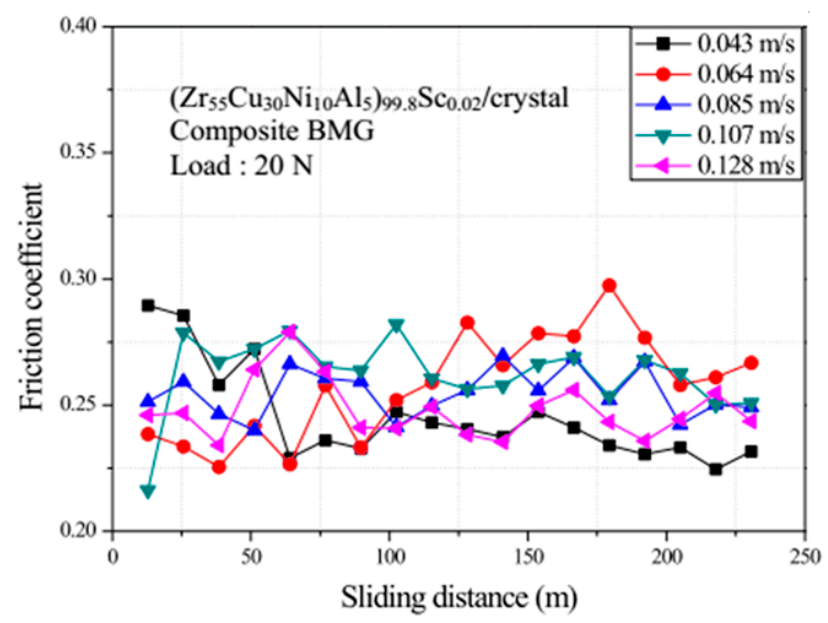

Figure 3. A plot of variation in friction coefficients at different sliding velocities under a $20 \mathrm{~N}$ load versus sliding distance.

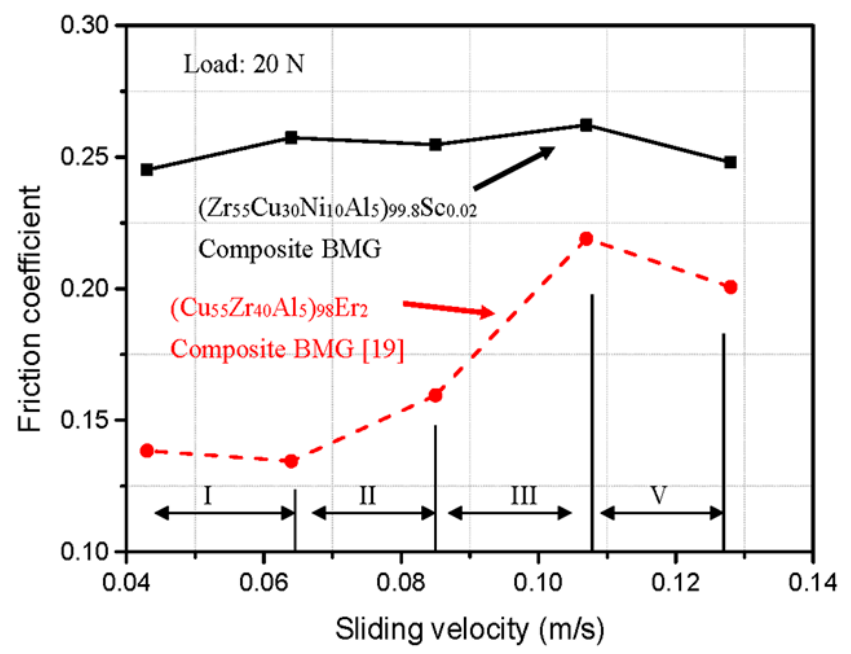

Figure 4. The relationship between the average coefficient versus sliding velocity for two composite BMGs under the same load of $20 \mathrm{~N}$. 
The distance-dependent nature of various friction coefficients can be classified into the following stages [20]. At stage I (early stage), the plowing of the surface controls the friction coefficient. In this state, no significant role is played by adhesion because of the surface-contaminated nature [20]. At stage II, because of an increase in adhesion the friction coefficient begins to rise slowly. At stage III, because of a higher wear rate a steep increase in slope is caused by the number of wear particles rapidly increasing and being entrapped between the sliding surfaces. At stage IV, the number of wear particles entrapped at the interface does not remain constant. At stage $\mathrm{V}$, the frictional force decreases because the plowing and asperity deformation weaken. The plowing is reduced because the wear particles cannot anchor to a polished hard surface. The average friction coefficient of the Sc-bearing Zr-based composite BMG is almost constant at approximately 0.25 (Figure 3) and is independent of the sliding velocity. This fact indicates that the wear particles entrapped at the interface between the hard disk and the composite BMG remains constant [19]. This difference might be caused by the relatively softer microhardness of the $\left(\mathrm{Zr}_{55} \mathrm{Cu}_{30} \mathrm{Ni}_{10} \mathrm{Al}_{5}\right)_{99.98} \mathrm{Sc}_{0.02}$ composite BMG at $519 \mathrm{Hv}$ compared with the $\left(\mathrm{Cu}_{55} \mathrm{Zr}_{40} \mathrm{~A}_{15}\right)_{98} \mathrm{Er}_{2}$ composite BMG at $530 \mathrm{Hv}$. A friction coefficient of 0.25 appears reasonable because it is close to the value of 0.2 in the $\mathrm{Zr}_{52.5} \mathrm{Cu}_{17.9} \mathrm{Ni}_{14.6} \mathrm{Ti}_{5} \mathrm{Al}_{10}$ composite BMG [3] in a pin-on-disk test under oil lubrication by using a high carbon and chromium-containing low alloy steel, AISI/ASTM 52100 bearing steel, as the counter surface under a load of $4.95 \mathrm{~N}$ at a velocity of $0.25 \mathrm{~m} / \mathrm{s}$.

\subsection{Worn Surface Characteristic}

Figure 5 exhibits the images of wear tracks under different conditions after sliding wear tests on the surface of the $440 \mathrm{C}$ steel disk. The debris of $\left(\mathrm{Zr}_{55} \mathrm{Cu}_{30} \mathrm{Ni}_{10} \mathrm{Al}_{5}\right)_{99.98} \mathrm{Sc}_{0.02}$ composite BMG scaled off from the pin with adhesive composite BMG, and patches adhered to the disk surface. The patches were plowed across the disk surface, formed cavities, and dragged traces along the wear track. More transferred materials were observed for the $\left(\mathrm{Zr}_{55} \mathrm{Cu}_{30} \mathrm{Ni}_{10} \mathrm{Al}_{5}\right)_{99.98} \mathrm{Sc}_{0.02}$ composite BMG than for the $\left(\mathrm{Cu}_{55} \mathrm{Zr}_{40} \mathrm{Al}_{5}\right)_{98} \mathrm{Er}_{2}$ composite BMG [19,21], and the disk surface was ploughed severely. The SEM (scanning electron microscopy) images of the composite BMG are shown in Figure 6. The composite BMG has experienced severe plastic deformation evidenced by the morphology of the track in Figure 6 . The worn surface of the $\left(\mathrm{Zr}_{55} \mathrm{Cu}_{30} \mathrm{Ni}_{10} \mathrm{Al}_{5}\right)_{99.98} \mathrm{Sc}_{0.02}$ composite BMG exhibited distinct grooves and craters. In addition, a higher number of cracks appeared on the $\left(\mathrm{Zr}_{55} \mathrm{Cu}_{30} \mathrm{Ni}_{10} \mathrm{Al}_{5}\right)_{99.98} \mathrm{Sc}_{0.02}$ composite BMG surface.

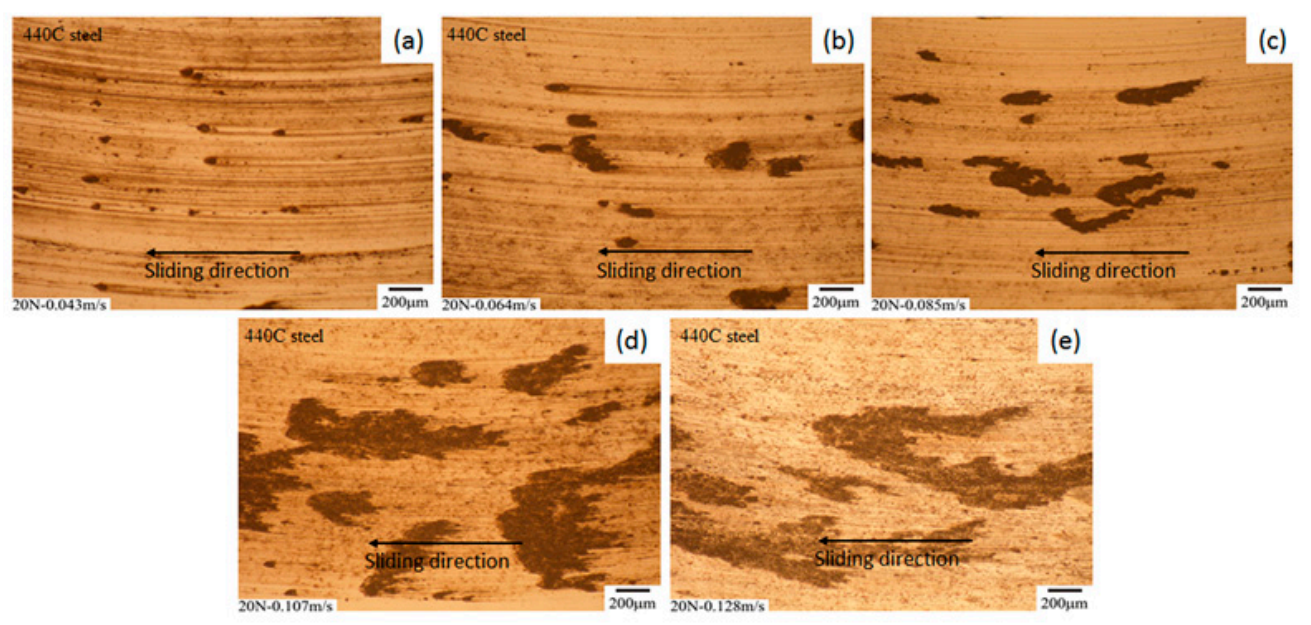

Figure 5. Disk (440C steel) surface images of a wear track under a $20 \mathrm{~N}$ load at sliding velocities of (a) $0.043 \mathrm{~m} / \mathrm{s}$, (b) $0.064 \mathrm{~m} / \mathrm{s}$, (c) $0.085 \mathrm{~m} / \mathrm{s}$, (d) $0.107 \mathrm{~m} / \mathrm{s}$, and (e) $0.128 \mathrm{~m} / \mathrm{s}$. 

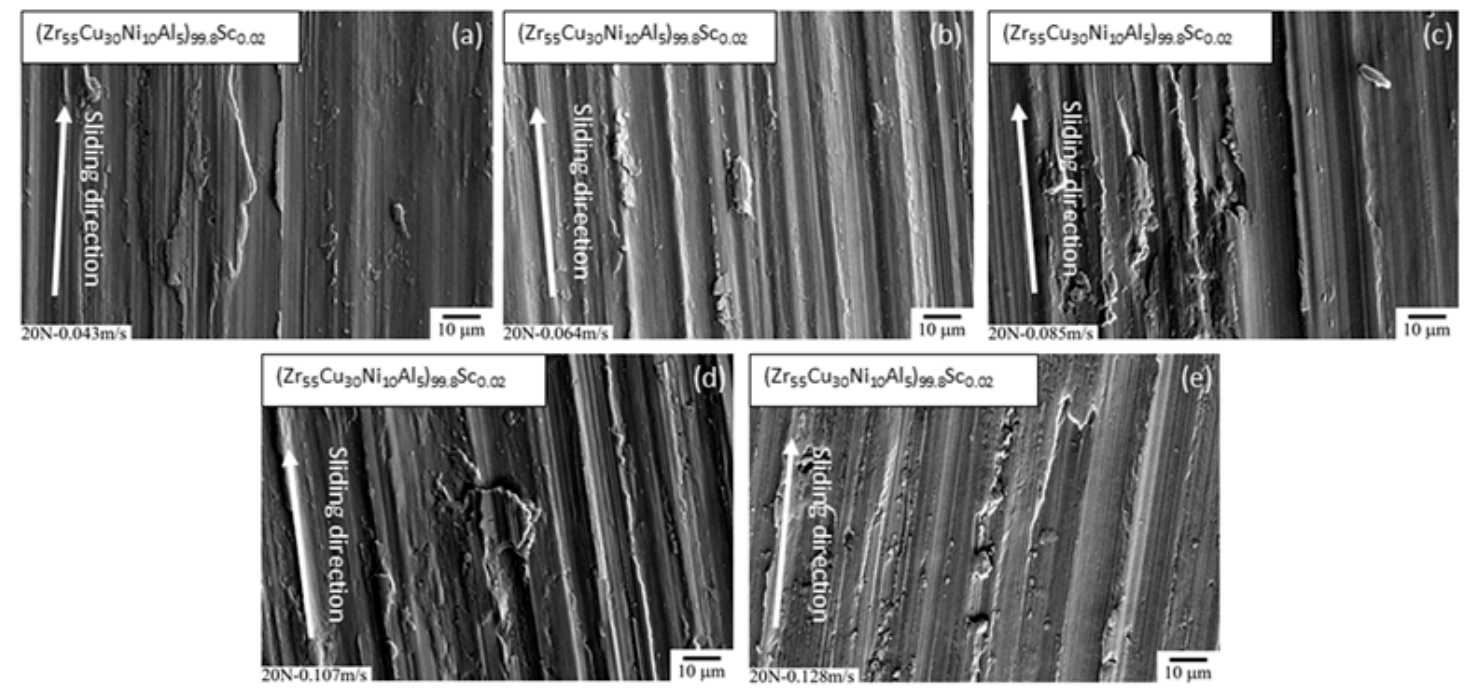

Figure 6. Scanning electron microscopy (SEM) images of a worn surface tested under a $20 \mathrm{~N}$ load at sliding velocities of (a) $0.043 \mathrm{~m} / \mathrm{s}$, (b) $0.064 \mathrm{~m} / \mathrm{s}$, (c) $0.085 \mathrm{~m} / \mathrm{s}$, (d) $0.107 \mathrm{~m} / \mathrm{s}$, and (e) $0.128 \mathrm{~m} / \mathrm{s}$ for the Sc-bearing Zr-based composite BMG.

Because of the severe plastic deformation during the sliding test, the worn surface of the $\left(\mathrm{Zr}_{55} \mathrm{Cu}_{30} \mathrm{Ni}_{10} \mathrm{Al}_{5}\right)_{99.98} \mathrm{Sc}_{0.02}$ composite BMG exhibited fine abrasion marks, tearing, and grooving [1]. Besides the plastic deformation, evidently distinct grooves and debris occurred on both sides of the grooves. Previous studies have reported these wear features $[19,21]$. The chemical analyses of the selected worn surfaces are depicted in Figure 7 for the $\left(\mathrm{Zr}_{55} \mathrm{Cu}_{30} \mathrm{Ni}_{10} \mathrm{Al}_{5}\right)_{99.98} \mathrm{Sc}_{0.02}$ composite BMG. Most debris adhered to the $\left(\mathrm{Zr}_{55} \mathrm{Cu}_{30} \mathrm{Ni}_{10} \mathrm{Al}_{5}\right)_{99.98} \mathrm{Sc}_{0.02}$ composite BMG surface, and least to the disk surface of $440 \mathrm{C}$ stainless steel. Debris I on the worn surface from the energy-dispersive X-ray spectroscopy (EDX) exhibited the same constituent elements as those exhibited by the $\left(\mathrm{Zr}_{55} \mathrm{Cu}_{30} \mathrm{Ni}_{10} \mathrm{Al}_{5}\right)_{99.98} \mathrm{Sc}_{0.02}$ composite BMG (Figure 7). Debris II exhibited a strong iron peak in the EDX analysis that originated from the 440C steel disk (Figure 7).

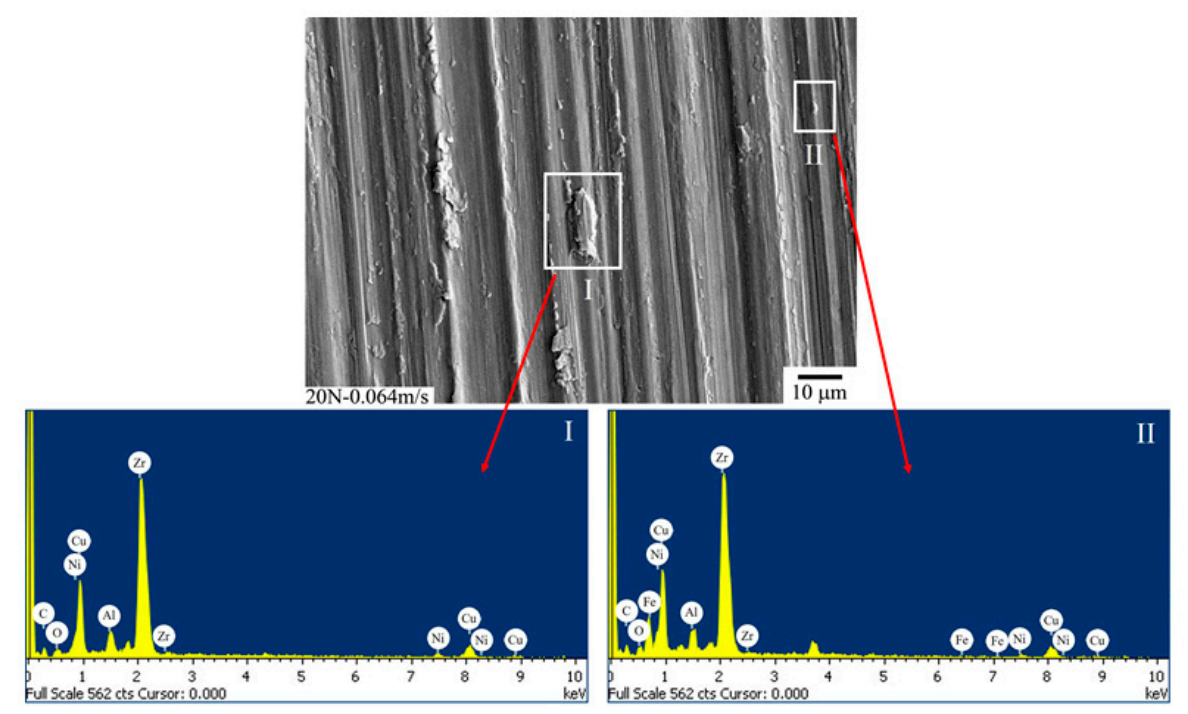

Figure 7. Scanning electron microscopy (SEM) image of a worn surface under a $20 \mathrm{~N}$ load, and the compositions of Debris I and II at a sliding velocity of $0.064 \mathrm{~m} / \mathrm{s}$. 
The composition of EDX analysis in Figure 7 for debris I on the worn surface is as follows: Zr 54.98, $\mathrm{Cu}$ 29.96, $\mathrm{Al}$ 9.99, Ni 4.97, C 0.06, and O 0.04 in at\%. That for debris II is $\mathrm{Zr}$ 53.83, Cu 28.15, Fe 7.81, $\mathrm{Al} 6.67, \mathrm{Ni} 3.45, \mathrm{C} 0.05$, and $\mathrm{O} 0.04 \mathrm{in}$ at $\%$. Although a contamination of iron peak originating from the $440 \mathrm{C}$ steel disk, the compositional difference between these two sources of debris is not very significant at around 1 at $\%$.

\subsection{Wear Rate and Wear Coefficient}

Wear rates of the Sc-bearing Zr-based composite BMG under a $20 \mathrm{~N}$ load at different sliding velocities are plotted in Figure 8. Wear rates of the $\left(\mathrm{Zr}_{55} \mathrm{Cu}_{30} \mathrm{Ni}_{10} \mathrm{Al}_{5}\right)_{99.98} \mathrm{Sc}_{0.02}$ composite BMG ranged from $4.8 \times 10^{-8}$ to $5.9 \times 10^{-8} \mathrm{~kg} / \mathrm{m}$ and the standard error was $3.8 \times 10^{-9} \mathrm{~kg} / \mathrm{m}$, approximately $7.1 \%$ of the mean value. Thus, the wear rate of the $\left(\mathrm{Zr}_{55} \mathrm{Cu}_{30} \mathrm{Ni}_{10} \mathrm{Al}_{5}\right)_{99.98} \mathrm{Sc}_{0.02}$ composite BMG was one order higher than that of $\left(\mathrm{Cu}_{55} \mathrm{Zr}_{40} \mathrm{Al}_{5}\right)_{98} \mathrm{Er}_{2}$, which ranged from $1.7 \times 10^{-9}$ to $2.4 \times 10^{-9} \mathrm{~kg} / \mathrm{m}$, both under the same loads. This trend is attributed to the higher hardness of the $\left(\mathrm{Cu}_{55} \mathrm{Zr}_{40} \mathrm{Al}_{5}\right)_{98} \mathrm{Er}_{2}$ composite BMG. The values of wear coefficient $(\mathrm{k})$ was obtained by using the equation proposed by Rabinowicz [20]. The density of the $\left(\mathrm{Zr}_{55} \mathrm{Cu}_{30} \mathrm{Ni}_{10} \mathrm{Al}_{5}\right)_{99.98} \mathrm{Sc}_{0.02}$ composite $\mathrm{BMG}$ was $6.77 \mathrm{~g} / \mathrm{cm}^{3}$, as determined using the Archimedes method. The microhardness was $519 \mathrm{Hv}$, and the distance of sliding was $230.6 \mathrm{~m}$ during the wear test. The $\mathrm{k}$ values ranged from $1.8 \times 10^{-3}$ to $2.4 \times 10^{-3}$ (Figure 9) and were higher than those of the $\left(\mathrm{Cu}_{55} \mathrm{Zr}_{40} \mathrm{Al}_{5}\right)_{98} \mathrm{Er}_{2}$ composite BMG (from $5.8 \times 10^{-4}$ to $8.3 \times 10^{-4}$ [21]) and the $\mathrm{Zr}_{48} \mathrm{Cu}_{45-\mathrm{x}} \mathrm{Al}_{7} \mathrm{Ag}_{\mathrm{x}}$ composite BMG ( $\mathrm{x}=0,2,5$, and 8 at $\%$; from $2.4 \times 10^{-4}$ to $5.4 \times 10^{-4}$ [5]). The wear behavior of the Sc-bearing Zr-based composite BMG was more critical than that of the Er-bearing Cu-based composite BMG.

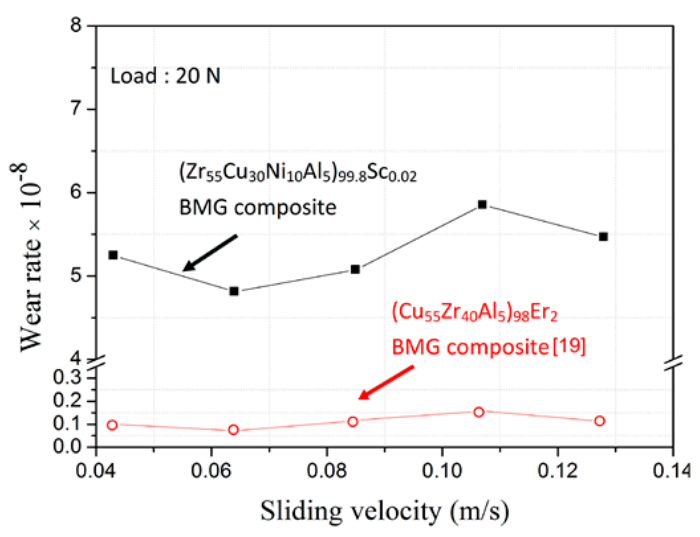

Figure 8. A plot of friction coefficient versus sliding velocity for the Sc-bearing Zr-based composite BMG.

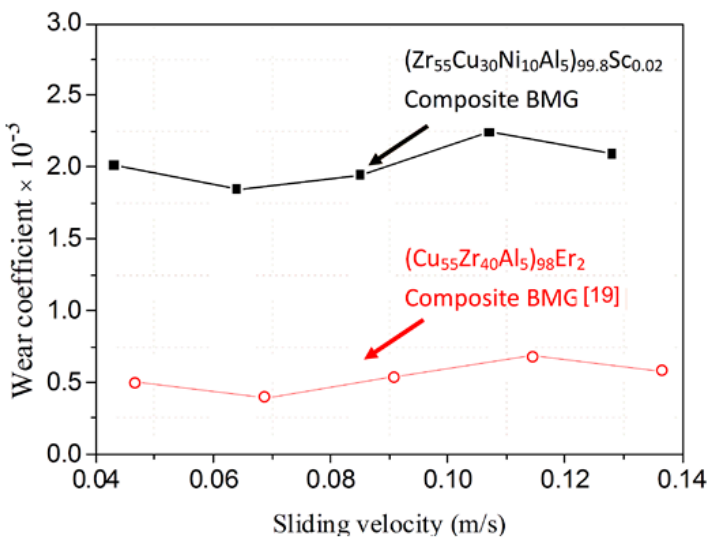

Figure 9. A plot of wear coefficient versus sliding velocity for the Sc-bearing Zr-based composite BMG. 


\section{Conclusions}

The original glassy $\left(\mathrm{Zr}_{55} \mathrm{Cu}_{30} \mathrm{Ni}_{10} \mathrm{Al}_{5}\right)_{99.98} \mathrm{Sc}_{0.02} / \mathrm{CuZr}_{2}$ nanocrystal composite structure remained the same without phase transformation during the wear test under $440 \mathrm{C}$ disk with oil lubrication and $20 \mathrm{~N}$ loads. Because of the intrinsic softness of the Sc-bearing Zr-based composite BMG, $\left(\mathrm{Zr}_{55} \mathrm{Cu}_{30} \mathrm{Ni}_{10} \mathrm{Al}_{5}\right)_{99.98} \mathrm{Sc}_{0.02} / \mathrm{CuZr}_{2}$, its wear tracks and worn surface underwent severe deformation. This deformation behaviour resulted in a higher wear coefficient and wear rate than those of the $\left(\mathrm{Cu}_{55} \mathrm{Zr}_{40} \mathrm{Al}_{5}\right)_{98} \mathrm{Er}_{2}$ composite BMG. The worn composite BMG particles entrapped at the interface remained a constant number, leading to a constant friction coefficient of approximately 0.25 for the Sc-bearing Zr-based composite BMG; this friction coefficient was independent of the sliding velocity. $\mathrm{CuZr}_{2}$ is harder than $\mathrm{Zr}$-based $\left(\mathrm{Zr}_{55} \mathrm{Cu}_{30} \mathrm{Al}_{10} \mathrm{Ni}_{5}\right)_{99.98} \mathrm{Sc}_{0.02}$ bulk amorphous matrix. Therefore, it is an attractive bearing and shaft material for industrial application.

Author Contributions: Conceptualization, editing and funding acquisition, S.-H.W.; supervision and methodology, C.-C.C.; investigation and analysis, H.-H.C.; TEM investigation, R.-T.H.; conceptualization, H.-Y.C.; typing and plot, C.-A.H.; review and editing, P.K.L. All authors have read and agreed to the published version of the manuscript.

Funding: This research received funding support from the MOST (Ministry of Science and Technology) of Taiwan under grants MOST 108-2221-E-019-036 and MOST 109-2221-E-019-047.

Acknowledgments: P.K.L. very much appreciates the support from the National Science Foundation (DMR-1611180 and 1809640) with the program directors, Judith Yang, Gary Shiflet, and Diana Farkas.

Conflicts of Interest: The authors declare no conflict of interest.

\section{Appendix A}

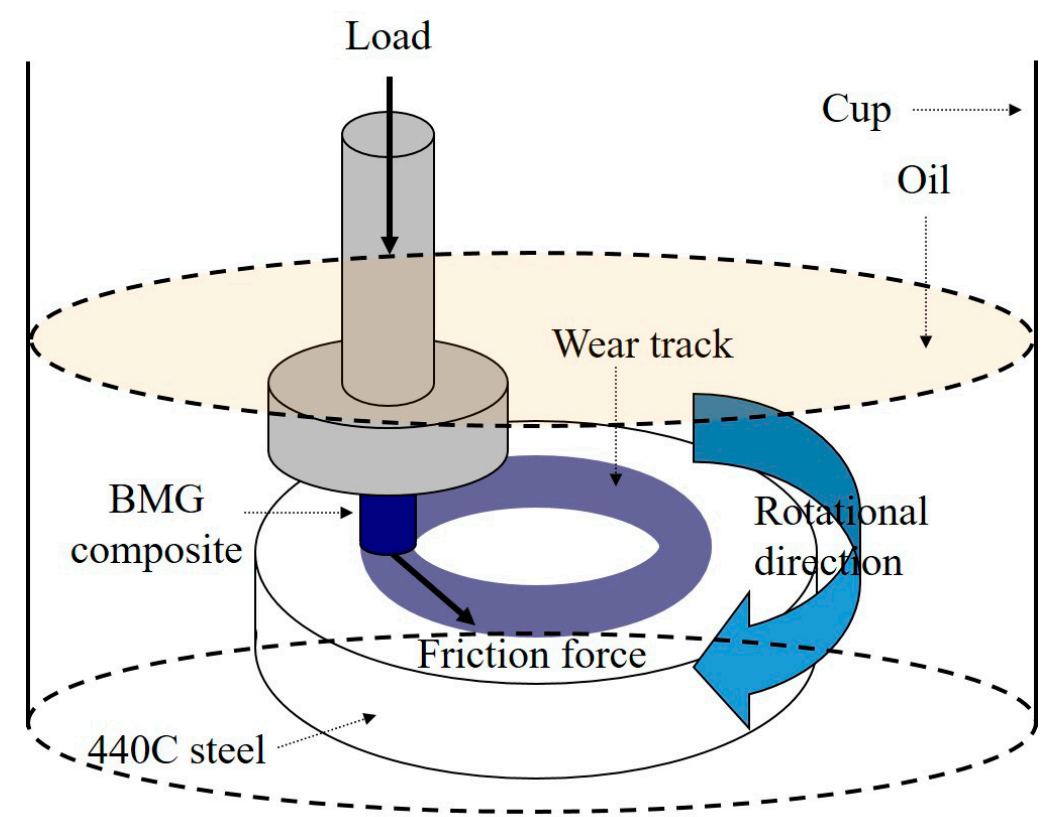

Figure A1. Illustration of pin-on-disk apparatus for lubricated sliding wear test.

\section{References}

1. Gloriant, T. Microhardness and abrasive wear resistance of metallic glasses and nanostructured composite materials. J. Non-Cryst. Solids 2003, 316, 96-103. [CrossRef]

2. Anis, M.; Rainforth, W.M.; Davies, H.A. Wear behaviour of rapidly solidified $\mathrm{Fe}_{68} \mathrm{Cr}_{18} \mathrm{Mo}_{2} \mathrm{~B}_{12}$ alloys. Wear 1994, 172, 135-145. [CrossRef]

3. Blau, P.J. Friction and wear of a Zr-based amorphous metal alloy under dry and lubricated conditions. Wear 2001, 250, 431-434. [CrossRef] 
4. Ma, M.Z.; Liu, R.P.; Xiao, Y.; Lou, D.C.; Liu, L.; Wang, Q.; Wang, W.K. Wear resistance of Zr-based bulk metallic glass applied in bearing rollers. Mater. Sci. Eng. A 2004, 386, 326-330. [CrossRef]

5. Zhang, G.Q.; Li, X.J.; Shao, M.; Wang, L.N.; Yang, J.L.; Gao, L.P.; Chen, L.Y.; Liu, C.X. Wear behavior of a series of Zr-based bulk metallic glasses. Mater. Sci. Eng. A 2008, 475, 124-127. [CrossRef]

6. Fu, X.Y.; Kasai, T.; Falk, M.L.; Rigney, D.A. Sliding behavior of metallic glass: Part I. Experimental investigations. Wear 2001, 250, 409-419. [CrossRef]

7. Bhatt, J.; Kumar, S.; Dong, C.; Murty, B.S. Tribological behaviour of $\mathrm{Cu}_{60} \mathrm{Zr}_{30} \mathrm{Ti}_{10}$ bulk metallic glass. Mater. Sci. Eng. A 2007, 458, 290-294. [CrossRef]

8. Kim, Y.H.; Inoue, A.; Masumoto, T. Ultrahigh tensile strengths of $\mathrm{Al}_{88} \mathrm{Y}_{2} \mathrm{Ni}_{9} \mathrm{M}_{1}(\mathrm{M}=\mathrm{Mn}$ or Fe) amorphous alloys containing finely dispersed fcc-Al particles. Mater. Trans. JIM 1990, 31, 747-749. [CrossRef]

9. Chen, H.; He, Y.; Shiflet, G.J.; Poon, S.J. Mechanical properties of partially crystallized aluminum based metallic glasses. Scr. Metall. Mater. 1991, 25, 1421-1424. [CrossRef]

10. Yoshizawa, Y.; Oguma, S.; Yamauchi, K. New Fe-based soft magnetic alloys composed of ultrafine grain structure. J. Appl. Phys. 1988, 64, 6044-6046. [CrossRef]

11. Suzuki, K.; Kataoka, N.; Inoue, A.; Makino, A.; Masumoto, T. High saturation magnetization and soft magnetic properties of bcc Fe-Zr-B alloys with ultrafine grain structure. Mater. Trans. JIM 1990, 31, 743-746. [CrossRef]

12. Croat, J.J.; Herbst, J.F.; Lee, R.W.; Pinkerton, F.E. Pr-Fe and Nd-Fe-based materials: A new class of high-performance permanent magnets (invited). J. Appl. Phys. 1984, 55, 2078-2082. [CrossRef]

13. Pan, M.X.; Wei, B.C.; Xia, L.; Wang, W.H.; Zhao, D.; Zhang, Z.; Han, B.S. Magnetic properties and microstructural characteristics of bulk Nd-Al-Fe-Co glassy alloys. Intermetallics 2002, 10, 1215-1219. [CrossRef]

14. Inoue, A. Bulk amorphous alloys with soft and hard magnetic properties. Mater. Sci. Eng. A 1997, 226-228, 357-363. [CrossRef]

15. Huang, Y.L.; Bracchi, A.; Niermann, T.; Seibt, M.; Danilov, D.; Nestler, B.; Scheider, S. Dendritic microstructure in the metallic glass matrix composite $\mathrm{Zr}_{56} \mathrm{Ti}_{14} \mathrm{Nb}_{5} \mathrm{Cu}_{7} \mathrm{Ni}_{6} \mathrm{Be}_{12}$. Scr. Mater. 2005, 53, 93-97. [CrossRef]

16. Maeda, S.; Yamasaki, T.; Yokoyama, Y.; Okai, D.; Fukami, T.; Kimura, H.M.; Inoue, A. Viscosity measurements of $\mathrm{Zr}_{55} \mathrm{Cu}_{30} \mathrm{Al}_{10} \mathrm{Ni}_{5}$ and $\mathrm{Zr}_{50} \mathrm{Cu}_{40-\mathrm{x}} \mathrm{Al}_{10} \mathrm{Pd}_{\mathrm{x}}(\mathrm{x}=0,3$ and 7 at.\%) supercooled liquid alloys by using a penetration viscometer. Mater. Sci. Eng. A 2007, 449-451, 203-206. [CrossRef]

17. ASTM G99-03 Standard Test Method for Wear Testing with a Pin-On-Disk Apparatus; ASTM International: West Conshohocken, PA, USA, 2003.

18. Stachowiak, G.W.; Batchelor, A.W. Engineering Tribology, 3rd ed.; Butterorth-Heinemann: Boston, MA, USA, 2005; ISBN 978-0-7506-7836-0.

19. Chou, C.C.; Wang, S.H.; Chung, H.H.; Liaw, P.K.; Liou, Y.; Huang, J.C.; Hsu, Y.Y. Wear behavior of Er-bearing Cu-based amorphous/crystal BMG composite under oil lubrication. Intermetallics 2011, 19, 1216-1221. [CrossRef]

20. Rabinowicz, E. Friction and Wear of Material, 2nd ed.; Wiley-Interscience: Hoboken, NJ, USA, 1995; ISBN 978-0471830849.

21. Suh, N.P.; Sin, H.C. The genesis of friction. Wear 1981, 69, 91-114. [CrossRef]

(C) 2020 by the authors. Licensee MDPI, Basel, Switzerland. This article is an open access article distributed under the terms and conditions of the Creative Commons Attribution (CC BY) license (http://creativecommons.org/licenses/by/4.0/). 